\title{
National Security, Values and Postmodern Society
}

\author{
Audronė PETRAUSKAITE் ${ }^{1}$, Rolanda KAZLAUSKAITE் MARKELIENÉ $\dot{1}^{2}$ \\ ${ }^{1,2}$ General Jonas Žemaitis Military Academy of Lithuania, Department of Humanities, \\ Silo 5A, Vilnius, Lithuania

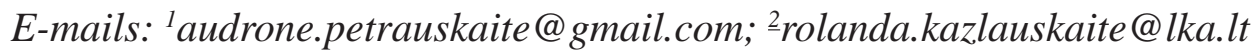

\begin{abstract}
Postmodernity as a concept of contemporary society together with technological progress and globalization caused changes in orientation of values as well as the transformation of individual and collective identity. Thus, increased vulnerability, both of individuals and society, caused the character of threats to national security. The aim of the article is to analyze the contemporary threats to national security as a phenomenon of a postmodern society, emphasizing the crisis of values as well as of the identity. Postmodern threats forced to revise traditional point of view on the concept of national security and demands to be based on comprehensive approach on the issues of security and defense. This article is an attempt to make an analysis on the topic of national security in an interdisciplinary context. After analyzing the actual threats to the security of the Republic of Lithuania, it was determined that the interaction of many of these threats with the crisis of values is evident. This allows to confirm the importance of further discussions and scientific research on the issues of values and identity in context of national security in postmodern society.
\end{abstract}

KEY WORDS: postmodernism, utilitarianism, consumerism, national security, threats to national security, orientation of values, postmodern identity

\section{Introduction}

Postmodernity as the phenomenon usually explores economical or cultural condition of contemporary society. Postmodernity is a typical term of art, music and literature rather than national security as well as national security is a topic of political, defense or security sciences rather than humanities. The end of 20th and the beginning of $21 \mathrm{st}$ century drastically changed traditional understanding of national security, which was oriented toward foreign affairs of the country. The political changes after the Cold War and global transformation in social, economic and political life under rapid development of information technologies brought a great challenge to the governments of countries. Usually enemy is using weakness point of the state for the attack - its defense system, political disagreements, social instability, the lack of energy recourses, etc. According to contemporary security situation every state faces a lot of diverse threats which are fast changing, unpredictable and uncountable. But the last decades has already shown that hybrid character of contemporary threats to national security and unconventional methods of warfare, such as terrorism and information attacks, are targeting the societies and individuals, in particular using their weaknesses in mind, emotions and morality. It became evident that the matters of security and defense, as primary interest of the country, made the shift from international affairs into the sphere of human affairs. This shift is caused on the specific features of postmodernity as cultural characteristic of the society in the 21 st century.

The process of globalization and rapid development of technologies raised a lot of transformations of the society. Some of them, maybe the most important and the most controversial are these: the process of society fragmentation based on the idea of individualization and localization, changes of collective and individual identity, replacement of the priorities in the system of values, etc. All these brought about many problems and difficulties for all governmental institutions and for the state security and defense system included because it is allowed to use the societies and individuals against the state. All efforts to solve these problems of the state without understanding the nature of postmodernity as the essence of postmodern society and postmodern individual are hopeless. Contemporary threats to national security demands comprehensive approach and complex analysis of various sciences - political, social and humanities - looking for mutually agreed solutions to the security and defense issues of the state.

The aim of the article is to analyze the contemporary threats to national security as a phenomenon of a postmodern society, emphasizing the crisis of collective and individual identity, the decline of values as manifestation of society and individual.

This research was made by interdisciplinary approach - i.e. on the basis of philosophical, political and sociological theories of postmodernity, concept of national security, identity and values. Methodology of this scientific research is based on the concept of postmodernism, utilitarianism as ethical theory and consumerism as a main idea of postmodern society.

Corresponding author

E-mail address: audrone.petrauskaite@gmail.com 


\section{Postmodernity and National Security: the Issues of Values and Identity}

Postmodernism can be explained by the viewpoint of various sciences, emphasizing different aspects of its wisdom. The main problem of Postmodernism is its conception in the context of the development of society: whether this is a new phase in the development of society or it is just a new stage in the era of Modernism. Many authors have stated that the intellectual, technological, societal, political, economic and cultural developments that have occurred at the end of 20th century reflect new way of thinking and justify new era of the development of the society - Postmodernism [1]. Some of scholars suggest that Postmodernism is not so differentiated in the concept of Modernism (its ideas, values' orientation) so it is only a continuation of modern society [2]. By this point of view, postmodernism can be characterized as the reaction of society to Modernism with some disillusion of it, some discontent and debate with it and with the attempt to modify it [3]. According Fredric Jameson, Postmodernism is a culturally dominant concept of late capitalism. It means that "postmodernism is what you have when the modernization process is complete and nature is gone for good" and "it is a more fully human world than the older one, but one in which "culture" has become a veritable "second nature"[4].

Despite diversities and differences in explanation and understanding, the impact of Postmodernism on the development of the society should be undeniable. It has permeated ideas, discourses, displays which are reflected in music, architecture, literature as well as in economics and management, in politics and social life. Postmodernism could be described as the society's disappointment with Modernism, its reaction to the ideals, which were blown up. Postmodernism identifies the existence of many realities and refuses to recognize the existence of universal laws and grand theories [5]. Postmodernism denies consistency of any ideas and life events caused a certain chaos in the mind of the individual.

The influence of Postmodernism on the system on values is evident as well. Principles of Postmodernism have brought a diversity of values into the minds of individuals. The disappointment in the optimism of Modernity raised the unbelief in universal morality. Postmodern understanding of ethics denies objectivity of morality laying on personal morality and private codes of ethics: person is free to create moral principles according his subjective opinion and without the need to follow traditional values and rules. This conceptual statement left individuals free to choose value orientation. Postmodern principle about validation of all religions increased number of personal choices in beliefs as well as transnational communication opened the doors for various and alternative systems of values. Under the impact of globalization and enhanced process of internationalization the diversity of choices in value orientations has increased what was reflected in the society's way of thinking, way of behavior and style of life.

Postmodernity doesn't change the system of values: without any doubt traditional, universal values, reflected in traditional religions, traditional ethical concepts, still exist and became maybe actual and more universal. Postmodernism changed the way of formation personal system of values facing individuals alone in difficult choice of priorities.

The values are being formed by individuals basically on the system of values of a society (based on traditions, religion, education system, governmental institutions, public organizations, mass-media, etc.). Postmodernism has brought about big changes in the tendencies of social and cultural development of the societies together with technological progress and economic growth. These changes were reflected in value orientation of society and allowed the scientists (economists and sociologists) to assert that new generations have different value priorities from older generations, because they have been brought up under much more secure living conditions. "While the generations that had experienced World War II, the Great Depression, and World War I would give top priority to economic and physical security, a growing share of the younger generation would give top priority to self-expression and the quality of life" [6]. The philosophers are not so optimistic about the changes in value orientation of the society.

Postmodernity is rooted on Modernism as a concept of contemporary society. Modern idea of individualization has arisen ideas of freedom, possibility of free choice and self-expression what have become main social and cultural factors of postmodern society development. Modern idea of technical progress and industrialization caused ideas of production and consumption as main economic and cultural factor of postmodernity. The concept of neoliberal society as postmodern form of democracy is grounded on philosophical ideas of Modernity. So, utilitarianism, as the main ethical theory of Modern society and liberal democracy has been reflected on postmodernity as well.

Utilitarianism, as ethical concept, possesses to evaluate any human act by its final result: whether it is good or evil for other people and states that the essential indicator of human performance and indicator as well is the principle of utility. Utility means the happiness as the sum of pleasure for human beings. Postmodernity transferred the meaning of happiness because it came together with consumerism as the main economic idea and consumer culture of postmodern society. Consumer culture began with a wide penetration of consumer goods into the everyday lives of people across social strata, that consumption was ignited through a new sense of fashion and taste, and finally that the culture was cemented through the development of infrastructures, organizations, and practices that took advantage of the new markets, namely, the rise of shopping, advertising, and marketing [7]. Consumer culture is trying to unify individuals and societies, and it is destroying personal uniqueness and national specific features at the same.

On the other hand, the concept of consumerism encourages the acquisition of goods and services in ever-increasing amounts, treats the utility as economic benefit / profit which is expressed in cash equivalents (dollars, euros, yuan, etc.) and possessed to count the profit. Simplified principle of utility became the basic index of any human action and a standard of economic, political, social and cultural activities of state institutions, private enterprises, education institutions and other organizations. This approach denies the essential idea of utilitarianism as well as it transforms the basic ethical category - the concept of goodness. The money becomes goodness and a fundamental value that measures the entire human activity. When the money became the core value and the same main goodness, other values such as morality, humanity, state, family and other universal or civic values have started to take less and less important part in human's life. 
Then it is easy to approve any amoral decisions or disgrace actions by the needs to get more profit $/$ money.

So, individuals are free for a lot of choices in their value orientations but in reality of consumer society they faced to only value counting in cash equivalent. This choice is reasoned by conceptual idea of postmodern society and in many cases individual has no other choices at all. Postmodern situation in value orientations of individuals and society is dangerous for both individuals and society as well as it threats for the state interests and national security.

The decline of values is means a collapse of the personality: the individuals become without morality and without identity as the consequence of it. When the individuals are loyal only for money and to money they can easy change the place of living, the job, the country, etc. The flexibility of contemporary human beings is explained by the process of globalization or technological progress. In other way, it can be also the consequence of a consumerism as the worldview of Postmodernity. Anyway, at the beginning of 21 st century some destructive factors to the consciousness and the identity of the society became evident.

The issues of collective and individual identity became more discussible in Postmodernity than in Modern period of Western civilization. The process of fragmentation and decentralization of the society, its transformation based on constantly changing ideas and fast going reforms in all spheres of life left individuals alone in this very complex situation. On the other hand, information technologies modified the ways of information transfer as well as the way of communication and the style of life as the consequence. It caused new forms of communities in social networks and new forms of collective identity.

The end of 20th century and the beginning of 21 st century is abundance of the identities which gave birth to the ambiguous interaction of state institutions, social movements and different identity forms [8]. The phenomenon of identity cannot be perceived as something uniform, stable and constant because personalities construct their individual identities throughout their lives, and this process is affected by different factors - national, social, religious, cultural, regional, professional, etc. [9]. But individual identity and its features undergo a major change because both the person and things lose their definiteness and continuity in Postmodern world [10].

The governmental institutions, as most powerful force in shaping collective identity of Modern society, are losing their dominant position in Postmodernity. It is caused by many reasons. One of the most important reasons is the conceptual nature of postmodernity denying any stability and domination of any institution. The diversity of social actors, involved and making influence on the creation of different forms of the identity, decreased the role of national governments as well. And the third, maybe, most important reason of the weakness of state actors in the process of formation of collective identity of the society is the decline of values. It is evident that orientation of values is playing the most important role in collective and individual identity. Neoliberalism, as the concept of postmodern democracy, faced Western governments to the crisis of values: the consumers' society is oriented toward money as core value. The authorities are forced to abide by the rules of the game, which are dictated by the consumerism and, in the same way, they follow the same principles and values which are a key element in the development of the society as well as it becomes the biggest risk for its security. Consumerism as a basis of value orientation cannot be the factor consolidating postmodern society.

Postmodernity has changed the character of the threats for national security: they are becoming more complex, faster changing and have more hybrid character. As a rule, they are targeting the consciousness of individuals and of the societies because of their moral weakness and value emptiness. The human factor is the main risk and main threat for the national security rezoned by moral decline of consumer society as well as it is the biggest challenge for national states and their governments because of complexity and diversity of postmodern world.

\section{National Security and the Threats to National Security in Postmodernity}

Most of famous scientific researchers (Walter Lippmann, Arnold Wolfers, David A. Baldwin, Barry Buzan, etc.) stressed the role play of values in the concept of national security. Anyway, the discussions on this topic are still continued because there is no unanimous opinion about the relation between national security as a value and other values of society. According to A. Wolfers, national security is at "the apex of the value pyramid and assumes it to constitute an absolute good to which all other values are subordinated" [11]. After 40 years, this statement was expanded by David A. Baldwin's idea that "security is valued by individuals, families, states, and other actors" so "security, however, is not the only thing they value; and the pursuit of security necessitates the sacrifice of other values" [12]. These opinions are laying on the Tom Hobbes' concept about security as the common interest of the citizens to protect their most important values - life, property, freedom and peace [13]. After the Cold War much of public policy debate was focused on whether and how to reallocate resources from security to other policy objectives and it was more important to have a concept of security that facilitates comparisons of the value of security with that of other goals [14]. Then it became very important to identify what kind of value is national security - prime, core or martial, what is the value of national security and can national security threaten to other values of the society? [15].

The discussions about the concept of national security are still continuing as well as a dispute about national security as the value of the society. However, according to the scientific point of view, the priorities of national security are determined by people or their groups according to the system of their values or taking into consideration the nature of threats to certain values. The beginning of 21 st century has brought about more questions and one of them, maybe the most important is whether the values of the society pose a threat to national security.

In 2014, the researchers of the department of Humanities (General Jonas Žemaitis Military Academy of Lithuania) made the test aiming to set up the militaries' opinions about the issues of Lithuanian national security. The questionnaire 
survey was conducted between officers, professional soldiers and cadets. The questions about external and internal threats to national security were included. While at that moment the public discussions in Lithuania were oriented toward the issues of national budgeting for security and defense, the results of the testing have shown that professional militaries assessed the decline in values as more danger threat to the security of the country than insufficient financing of its defense system (Fig. 1). The difference between the opinion of professional militaries $(36 \%)$ and the cadets $(18 \%)$, which have distinguished the crisis of values as the threat, could be explained by their life experience and professional knowledge. On the other hand, the both groups ( $47 \%$ and $48 \%$ of the respondents) mentioned the passivity of citizens as the threat to the state's security and defense system. According to the test results, the human factor is a very important factor in the system of national security as well as orientation of values of the society and individuals as essential guides for all human activities.

Thus, values can be important element of consolidation and mobilization of the society against threats as well as deconstructive factor for security and defense system of the country. The authorities in their strategic documents highlight the importance of values in ensuring national security. The National security strategy of the USA (2017) emphasizes the importance of such values (democracy, freedom as free press, free speech, and free thought) in consolidating society and increasing its resilience to contemporary threats [16]. The National security strategy of the Republic of Lithuania (2017) identifies 15 dangers, threats and risks and the last one of these was mentioned as a "crisis of values". This threat is explained as "disrespect for inherent human rights, downgrading of Christian values, family institution, liberal democracy and pluralistic society, spreading of anti-humanistic theories, religious doctrines and ideologies diminishing or denying the value of human life, inciting racial, national or religious discord, promoting or justifying violence, coercion and genocide" [17]. So the values as the factor of national security is emphasized in a different aspect: the US government expresses value as a consolidating factor in ensuring national security, the Government of the Republic of Lithuania treats values as a threat to national security of the country.

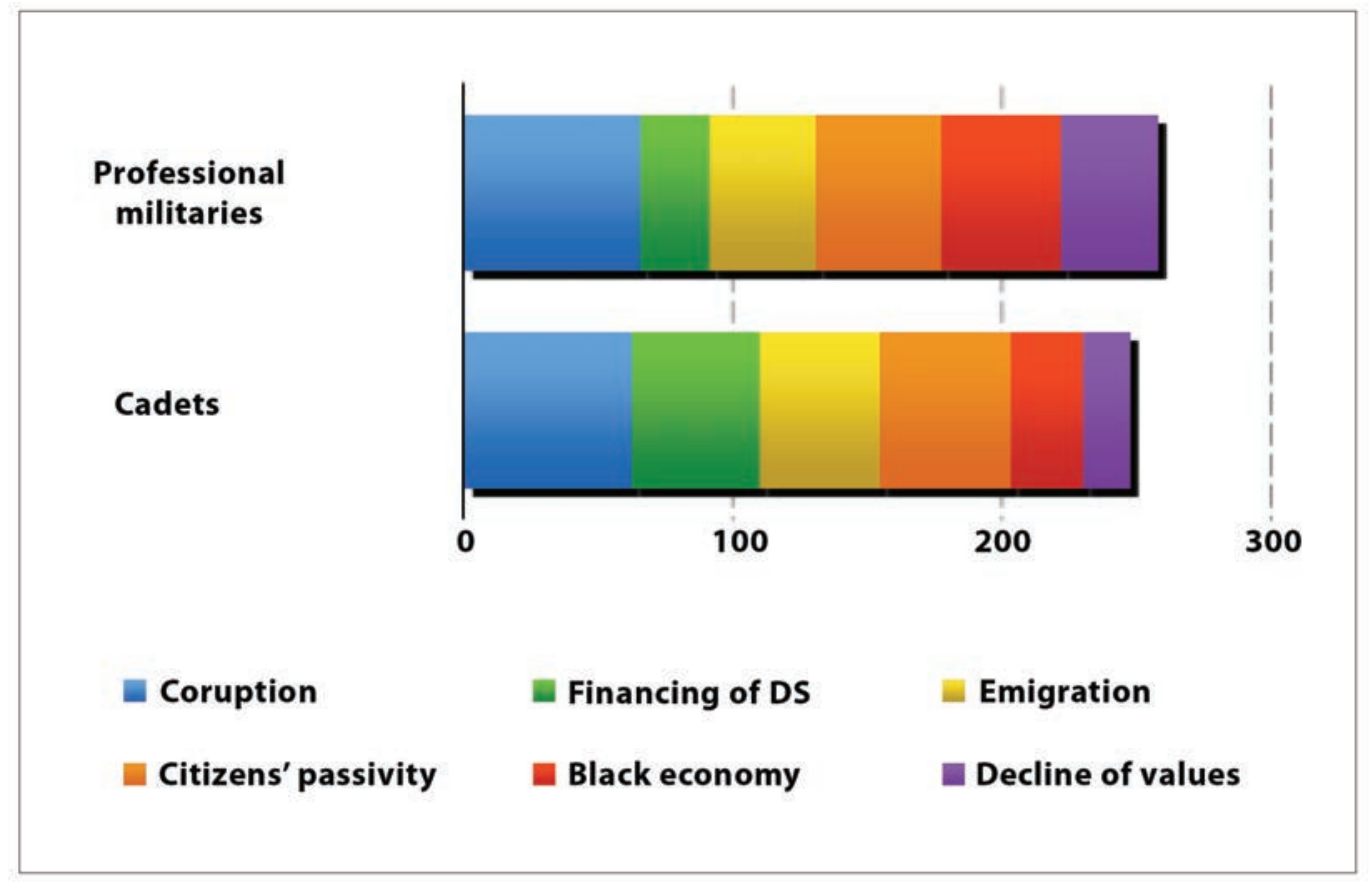

Fig. 1. The most important internal threats to national security (Test results, 2014)

Why does the government of Lithuania distinguish the values (or crisis of them) as a threat to the security of the country? Is it really serious threat to national security or just some warning about possible danger? How could it happened that the values of the society became the threat to its most important value - security and defense? These questions can cause serious scientific discussion and we need to come back to the issue of postmodernity as the concept of contemporary society looking for the answers.

Postmodernity has brought a diversity of life denying universal laws, values and world views as well as it caused the diversity of form and methods of self expression. This diversity is expressed in different ways - constructive and deconstructive as well. The last one has brought a lot of troubles for governmental institutions and society because it caused new forms of threats, hazards and risk for the state security. Traditional threats (military, social, economic) are still actual in postmodernity. However, such unconventional threats as terrorism or information attacks became more acute as well as corruption and organized crime began to play role of increasing danger to national security. All these 
unconventional (or non traditional treats) to national security are caused by the changes in the value orientation of the society. The main determinants of these changes are consumerism as the main economical idea and neoliberalism as a political concept of postmodern society. All unconventional threats are targeting weak points of postmodern society - moral vacuum in the consciousness of an individual who is being attempted to fill the consumer's values of society. So such treats as corruption, crime, terrorism, information attacks (propaganda) and masked military and intelligence tools can be named as postmodern threats to national security because of their specific determinants became actual in Postmodernity.

Corruption as the threat to national security is based on this weakness of the society. According to the scientific point of view, the most of the issues of corruption are laying on the values, attitudes and behavior of individuals as cultural context of society [18]. Consumers' society is based on the idea of seeking profit as expression of only goodness of life. So, the attitudes, behavior and consciousness of individuals are oriented toward this aim. Of course, the causes of corruption vary due to national social features (traditions, religions, etc.). However, in the era of globalization, these peculiarities become equal to one consumer's idea. According to National security strategy of the Republic of Lithuania (2017), corruption can "undermine the legitimate interests of individuals and the state, compromise the rule of law, reduce citizens' faith in democratic values, democratic institutions and reduce the attractiveness of the state to foreign investors" [19]. So, the corruption as the phenomenon of the society which caused its moral weakness, becomes a threat to national security, because it even more weakens society. Similar situation can be admitted with another postmodern threats: terrorism, information attacks (propaganda) and intelligence tools.

Terrorism is caused by different determinants: economical, political, social, cultural [20]. It uses radical ideas of religious, ethnic and political extremism and so tries to fill the values vacuum in the consciousness of individuals which are not satisfied in economic, social and/or political situation and which are not able individually to find true moral guidelines for their life activities. The methods of terrorists warfare against political opponents are justified by the principle of utility what has been found to be very appealing to the schematics of simplified and primitive utilitarianism.

The methods of intelligence service, directed against the state, also use people's moral weaknesses - greed, jealousy, fear, the feelings of dissatisfaction, mistrust, losing of ideals and believes, etc. All these human weaknesses are used by foreign countries to negatively influence the political system, military capabilities, law enforcement, social and economic stability of the country.

Unreasonable and misleading propaganda promotes mistrust and dissatisfaction with the state and its institutions aiming to weaken national and civic identity, citizen's resilience against the threats and to reduce the willingness to defend their state. By the way, in the information age, more favorable conditions for the use of information as a weapon against the state and its security have emerged than before. Information technologies gave opportunities to get a lot of information in different ways, but the access to information without education does not fulfill the purpose of developing an informed citizenry, ready to engage in meaningful debate and make decisions. People need to develop the competencies necessary to understand and evaluate the information - and misinformation — with which they are confronted on a daily basis [21]. Obviously, these competences of the individuals can be formed on the basis of fundamental sciences. But the governmental and commercial educational institutions are aiming to achieve more quantitative than qualitative results: more students in shorter period. Simplified principle utility of consumers does not let to waste time and money for "useless" knowledge and impractical competences such as mathematics, physics, philosophy, literature, art, etc. The idea of consumerism is making negative influence on both, the individuals universal competences that decrease their possibility for critical thinking and value orientation based on universal human values. In postmodernity, information can be used in propaganda cases as a weapon against an individual and society, destroying a personality and making society more fragmented and unsafe.

It is obvious that, the situation in orientation of values of the postmodern society makes the society more and more vulnerable. Postmodern threats to national security are oriented towards a crisis of values and identity, using the slogans which are very important for the society such as, for example, "the struggle for justice, equality, freedom" or "fight against corruption, human greed, money, consumerism, etc.". On the other hand, the nature of the post-modern threats shows that, after ignoring the stereotypes about money as the only and fundamental value, people still want to follow the principles of goodness, justice and other values in postmodern society.

The analysis of the threats to national security of Lithuania allows to assert that there is a deep interaction between the majoring of threats and the value orientation of society. Actually, the system of values and/or postmodern identity are determinants for some of postmodern treats, such as terrorism, radicalization and extremism, information threats, corruption and organized crime as well as other threats are also directly related to value orientations and postmodern identity of contemporary society ( Table 1.). Threats such as the demographic crisis, social exclusion, economic and energy dependence, are reasoned with the issues of the consumer society as well as they are making influence on the values and identity of the society and increasing their vulnerability to other threats (conventional military threats, instability in the region and world, etc.). The analysis of the threats to National security of Lithuania allows to assert that crisis of values is the most important threat in Postmodern period of the development of the society, and it influences other threats that are reasoned by the concept of Postmodernity. 
The interaction between the crisis of value and other threats to National Security of Lithuania.

\begin{tabular}{|c|c|}
\hline $\begin{array}{l}\text { Threats to National security of Lithuania } \\
\text { (according to National Security Strategy of the Republic } \\
\text { of Lithuania, 2017) }\end{array}$ & $\begin{array}{l}\text { Interaction with the crisis of values as the threat to } \\
\text { National security }\end{array}$ \\
\hline Conventional Military Threats & $\begin{array}{l}\text { Using the weakness of society in the willingness for } \\
\text { resilience and defense. }\end{array}$ \\
\hline Military and intelligence tools & $\begin{array}{l}\text { Using moral failures and/or moral aspersions of } \\
\text { individuals: lost of values, consumer's consciousness, } \\
\text { dissatisfaction, misunderstanding, feeling of injustice, } \\
\text { moral failures or sins. }\end{array}$ \\
\hline Threats to the unity of the Euro-Atlantic community & $\begin{array}{l}\text { Based on the clash of religious, cultures, systems of } \\
\text { values, fragmentation of collective identity. }\end{array}$ \\
\hline Instability in the region and in the world & $\begin{array}{l}\text { Based on the clash of religious, cultures, systems of } \\
\text { values, fragmentation of collective identity. }\end{array}$ \\
\hline Terrorism, extremism, radicalization & $\begin{array}{l}\text { Using the ideas of radicalism and extremism, based on } \\
\text { religious, ethnic and political clash; dissatisfaction in } \\
\text { economic, social and/or political situation. } \\
\text { Seeking "true values": moral and/or political, social } \\
\text { justice, freedom, equality, etc. }\end{array}$ \\
\hline Information threats & $\begin{array}{l}\text { Targeting value orientations and collective identity of } \\
\text { society. } \\
\text { Based on ideas of historical, social, political and moral } \\
\text { justice }\end{array}$ \\
\hline \multicolumn{2}{|l|}{ Cyber threats } \\
\hline $\begin{array}{l}\text { Economic and energy dependence, economic } \\
\text { vulnerability }\end{array}$ & Influence by the ideas of consumerism \\
\hline \multicolumn{2}{|l|}{$\begin{array}{l}\text { The development of unsafe nuclear energy near the } \\
\text { borders of the Republic of Lithuania, }\end{array}$} \\
\hline Social and regional exclusion & $\begin{array}{l}\text { Influenced by consumers consciousness and moral } \\
\text { vacuum }\end{array}$ \\
\hline Demographic crisis & $\begin{array}{l}\text { Influenced by consumers consciousness and moral } \\
\text { vacuum }\end{array}$ \\
\hline Corruption & Based on consumers consciousness and moral vacuum \\
\hline Organized crime & Based on consumers consciousness and moral vacuum \\
\hline State and international levels of extreme situations & \\
\hline
\end{tabular}

\section{Conclusions}

The last few decades of human history has transformed the character of society - its identity and values orientations. Mostly it is reasoned by the development of technologies and the process of globalization. These new social and economic processes transformed the concept of society into Postmodernity.

Postmodernity as an idea of denial of Modernity can be characterized by fragmentation and decentralization of the society, constantly changing ideas and fast going reforms. Consumerism as a key economic concept of society has transformed moral idea of utilitarianism from goodness to benefit. Together with technological progress and globalization it caused new way of thinking and communication, new forms of communities and the transformations of individual and collective identity.

The transformations in value orientation and identity increased vulnerability of individuals and society and caused the character of threats to national security. Contemporary threats have got more hybrid character mostly targeting the weakness of human society - its values and identity. So, contemporary threats to national security and defense can be named as postmodern.

The concept of Postmodernity does not deny the importance of universal human values as essential guides for humanbeing and societies. The crisis of values as moral vacuum in the consciousness of individuals and society became one of most important threats to National security and defense which is a vital value of postmodern society.

Postmodern threats forced to revise a traditional point of view on the concept of National security and demands to be based on a comprehensive approach on the issues of security and defense. This approach is based on the multiple concept of postmodernism, which focuses on research on the topic of national security in a variety of fields - humanitarian, political and social sciences. 


\section{References}

1. Harvey D. The Condition of Postmodernity, Basil Blackwell Publishers, Oxford 1989; Pippin R.B. Modernism as a Philosophical Problem: On the Dissatisfactions of European High Culture, Basil Blackwell Publishers, Oxford 1991; Jencks C. The Death of Modern Architecture: from what is Postmodernism, in From Modernism to Postmodernism: An Anthology. ed. Cahoone, L.E. Basil Blackwell Publishers, Oxford 1996.

2. Giddens A. The consequences of Modernity, Stanford University Press, Stanford 1990; Shin K.W. Postmodernism and a Christian Response, Pro Rege, Vol. 20, No.4, 1994, pp.15-25.

3. Cahoone L.E. The Ten Modernisms, in life in a Postmoden Culture, ed. G.1. Rossouw, HSRC Publishers, Pretoria 1995; Koornhof C., de Villiers C. J. Postmodernism and accounting: Mirror or myth?// Meditari Accountancy Research, Vol. 7, 1999, p. 145-164.

4. Jameson F. Postmodernism, or, the Cultural logic of late capitalism. Verso, USA, UK 1991, p. X (Introduction).

5. Montagna P. Modernism vs Postmodernism in Management Accounting, Critical Perspectives on Accounting, Vol. 8, 1997, pp.125-145.

6. Inglehart R. Globalisation and Postmodern values. The Washington Quarterly, winter, 2000, pp. 215-228.

7. Slater, D. Global Cultural Economy and consumerism. Public Culture Vol. 2, 1997, p.1-24.

8. Castells M. The Power of Identity. Blackwell Publishing, UK 2010.

9. Grigas R. Tautinès tapatybès drama, http://www.elibrary.lt/resursai/Ziniasklaida/LLKC/liaudies_kul- tura/Lk06_2. pdf, 09102010.

10. Lasch Ch. The Minimal Self; Psychic Survival in Troubled Times. Pan Books, London1985.

11. Wolfers A. "National Security" as an Ambiguous Symbol. /Political Science Quarterly, Vol. 67, No. 4. (Dec., 1952), p. 500.

12. Baldwin D. A. The concept of security. / Review of International Studies, Vol. 23, 1997, p.18.

13. Hobbes T. The Leviathan, Cambridge Univeristy Press, UK 2003, p. 121.

14. Baldwin D. A. The concept of security. / Review of International Studies, Vol. 23, 1997, p.24.

15. Baldwin D. A. The concept of security./ Review of International Studies, Vol. 23, 1997, p.5-26; Nyman, J. What is the value of security? Contextualising the negative/positive debate. Review of International Studies. Vol. 42. December 2016, pp. 821-839; Der Derian J. The Value of Security: Hobbes, Marx, Nietzsche, and Baudrillard. Ronnie Lipschutz (ed.), On Security, New York1995), pp. 24-45.

16. National Security strategy of th United States of America. December, 2017. Online: https://www.whitehouse.gov/wpcontent/uploads/2017/12/NSS-Final-12-18-2017-0905.pdf

17. Lietuvos Respublikos nacionalinio saugumo strategija, 201701 26. (National Security Strategy of the Republic of Lithuania, 2017). https:/www.e-tar.lt/portal/lt/legalAct/TAR.2627131DA3D2/LLwfQepmnD.

18. Holmes L. Corruption: A Very Short Introduction14. OUP, Oxford 2015 p. 60-62.

19. Lietuvos Respublikos nacionalinio saugumo strategija, 201701 26. (National Security Strategy of the Republic of Lithuania, 2017). https://www.e-tar.lt/portal/lt/legalAct/TAR.2627131DA3D2/LLwfQepmnD.

20. Krieger T., Meierrieks D. What causes terrorism? Public Choice, Vol. 147, 2011, p.4-5. online: https: //www. researchgate.net/publication/258833074_What_causes_terrorism

21. Saunders L. Information as the weapon. ACRL, 2013, p.310. online: http://www.ala.org/acrl/sites/ala.org.acrl/files/ content/conferences/confsandpreconfs/2013/papers/Saunders_Information.pdf. 